\title{
Antibiotic treatment of acute gastroenteritis in children
}

\section{[version 1; peer review: 2 approved]}

\section{Eugenia Bruzzese, Antonietta Giannattasio, Alfredo Guarino}

Department of Translational Medical Sciences-Section of Pediatrics, University of Naples Federico II, Via S. Pansini 5, Naples, 80131, Italy

V1 First published: 15 Feb 2018, 7(F1000 Faculty Rev):193

https://doi.org/10.12688/f1000research.12328.1

Latest published: 15 Feb 2018, 7(F1000 Faculty Rev):193

https://doi.org/10.12688/f1000research.12328.1

\section{Abstract}

Antibiotic therapy is not necessary for acute diarrhea in children, as rehydration is the key treatment and symptoms resolve generally without specific therapy. Searching for the etiology of gastroenteritis is not usually needed; however, it may be necessary if antimicrobial treatment is considered. The latter is left to the physician evaluation in the absence of clear indications. Antimicrobial treatment should be considered in severely sick children, in those who have chronic conditions or specific risk factors or in specific settings. Traveler's diarrhea, prolonged diarrhea, and antibiotic-associated diarrhea may also require antibiotic therapy. Depending on the severity of symptoms or based on risk of spreading, empiric therapy may be started while awaiting the results of microbiological investigations. The choice of antibiotic depends on suspected agents, host conditions, and local epidemiology. In most cases, empiric therapy should be started while awaiting such results. Empiric therapy may be started with oral co-trimoxazole or metronidazole, but in severe cases parenteral treatment with ceftriaxone or ciprofloxacin might be considered.

\section{Keywords}

gastroenteritis, diarrhoea, vomiting, antimicrobials, children

\section{Open Peer Review}

Approval Status

1 2

version 1

15 Feb 2018

Faculty Reviews are review articles written by the prestigious Members of Faculty Opinions. The articles are commissioned and peer reviewed before publication to ensure that the final, published version is comprehensive and accessible. The reviewers who approved the final version are listed with their names and affiliations.

1. Stephen Baker, University of Oxford, Oxford, UK

\section{Zulfiqar Bhutta, The Hospital for Sick} Children, Toronto, Canada Any comments on the article can be found at the end of the article. 
Corresponding author: Alfredo Guarino (alfguari@unina.it)

Author roles: Bruzzese E: Methodology, Resources, Writing - Original Draft Preparation; Giannattasio A: Methodology, Resources, Writing - Original Draft Preparation; Guarino A: Conceptualization, Supervision, Writing - Original Draft Preparation, Writing - Review \& Editing

Competing interests: No competing interests were disclosed.

Grant information: The author(s) declared that no grants were involved in supporting this work.

Copyright: ( 2018 Bruzzese E et al. This is an open access article distributed under the terms of the Creative Commons Attribution License, which permits unrestricted use, distribution, and reproduction in any medium, provided the original work is properly cited.

How to cite this article: Bruzzese E, Giannattasio A and Guarino A. Antibiotic treatment of acute gastroenteritis in children [version 1; peer review: 2 approved] F1000Research 2018, 7(F1000 Faculty Rev):193 https://doi.org/10.12688/f1000research.12328.1

First published: 15 Feb 2018, 7(F1000 Faculty Rev):193 https://doi.org/10.12688/f1000research.12328.1 


\section{Introduction}

Acute gastroenteritis (AGE) is one of the most common problems in infants and young children, especially in poor countries. It is caused by viral, bacterial, and parasitic agents, with an age-, host-, and location-based pattern. Etiology usually is not looked for, and oral rehydration therapy is the universal therapy. Active treatment with probiotics and antidiarrheal agents is suggested in adjunct to rehydration, as it reduces the duration and intensity of symptoms independently from etiology ${ }^{1}$. There are no clear indications for antimicrobial therapy; however, antibiotics are frequently prescribed. Overuse of antibiotics is associated with increased rates of antibiotic-resistant bacteria, unnecessary costs, and significant incidence of adverse events, and current guidelines are highly restrictive in recommending empiric antimicrobial therapy for AGE. Bacterial infections may be associated with the presence of specific clinical features, notably fever, abdominal pain, blood in the stool, and fecal leukocytes ${ }^{2}$. However, none of these features is reliable to support a bacterial etiology. In addition, many children with bacterial enteritis have negative stool cultures and, conversely, it is not uncommon to detect multiple bacterial and viral pathogens, making it difficult to give a causative role to a specific microorganism.

The application of a quantitative molecular approach showed that four agents (rotavirus, Cryptosporidium, enterotoxigenic Escherichia coli (ETEC) producing heat-stable toxin, and Shigella) account for the majority of cases of infectious diarrhea in African and Asian children younger than 5 years old ${ }^{3}$. It is a logical hypothesis that, if bacteria are causing gastroenteritis, antibiotic therapy could be effective in reducing the intensity and duration of symptoms and prevent infection spreading. Furthermore, specific antibiotic treatment may prevent serious complications such as sepsis and protracted diarrhea in children with underlying conditions such as immunosuppression or malnutrition. However, the indications for antibiotic therapy are not standardized, and randomized controlled trials are not available in children.

\section{Bacterial etiology of acute gastroenteritis in developing and developed countries}

The etiological pattern of bacteria causing acute diarrhea depends on geographical area. In developing countries, more than half a million infants and young children die each year because of AGE, and Vibrio cholerae still causes epidemics, but the most common bacterial agent is Shigella ${ }^{4}$. In Europe, the most common bacterial pathogens are Campylobacter, Salmonella spp., enteropathogenic E. coli (EPEC), and enteroaggregative E. coli $(\mathrm{EAEC})^{5,6}$. Clostridium difficile $(\mathrm{Cd})$ has emerged as a cause of community-acquired diarrheal illness, but local data report a relatively low burden ${ }^{7-9}$. In Ecuador, sub-Saharan Africa, and South Asia, Shigella is the main agent ${ }^{3,10}$. In a recent study from central China, pathogens were detected in $20 \%$ of 508 fecal samples from patients with acute diarrhea, under 5 years of age ${ }^{11}$. The most commonly detected pathogens were Salmonella spp. (8\%), diarrheagenic E. coli (5\%), Campylobacter jejuni (3\%), and Aeromonas spp. (2\%). In the developing region of China, Shigella was the most common bacterial agent of $\mathrm{AGE}^{12}$. In India, E. coli was the most common agent of AGE (31\%) followed by Shigella $(24 \%)$. Infections with two or more pathogens were observed in $34 \%$ of cases, with a predominant incidence in children younger than 2 years old ${ }^{13}$.

Bacterial pathogens account for $80 \%$ of cases of traveler's diarrhea $^{14}$. ETEC, enteroinvasive E. coli (EIEC), and EAEC are implicated in the majority of cases, but also Campylobacter, Salmonella, and Shigella play a substantial role.

\section{Current recommendations for the treatment of acute gastroenteritis}

Evidence-based indications for the management of children with AGE are that oral rehydration with hypo-osmolar solution is the key treatment and should be started as soon as possible'. The so-called active intervention in adjunct to rehydration includes specific probiotics such as Lactobacillus rhamnosus strain GG or Saccharomyces boulardii, or diosmectite or racecadotril. Active treatment reduces the intensity of symptoms and their duration independently of etiology ${ }^{15}$. However, the concept of active treatment of gastroenteritis is progressively pursued in children, and current recommendations for the use of probiotics and antidiarrheal drugs are available from several regions of the world, including the Asia-Pacific region ${ }^{15}$. According to the guidelines for the management of AGE, antibiotic therapy should not be given to the vast majority of children with AGE, unless specific conditions are present. Even in cases of proven bacterial gastroenteritis, antibiotic therapy is not routinely needed but should be considered only for specific pathogens or in defined clinical settings.

The routine use of antimicrobials for diarrhea in children is not recommended by the World Health Organization (WHO) except for clinically recognizable severe $\operatorname{cases}^{16}$. It is indicated in the following circumstances: cholera, shigellosis, dysenteric presentation of campylobacteriosis and non-typhoidal salmonellosis when they cause persistent diarrhea, and when host immune status is compromised for any reason including severe malnutrition, chronic disease, or lymphoproliferative disorders. Antimicrobial treatment should also be considered for: moderate/severe traveler's diarrhea or diarrhea accompanied by fever and/or bloody stools and diarrhea associated with another acute infection (e.g. pneumonia) requiring specific antimicrobial therapy. Similar indications are provided at a local level, but supporting evidence is weak or absent ${ }^{17,18}$.

\section{Antimicrobial prescribing patterns for acute gastroenteritis in developing and developed countries} Antibiotic therapy is sometimes recommended to shorten the duration and severity of symptoms of AGE as well as to decrease its transmission ${ }^{19,20}$. The emerging challenge of antibiotic resistance complicates treatment for bacterial diarrhea. Antimicrobial resistance among diarrheal pathogens is high in developing countries, where the use of antimicrobials is less restricted, and these rates are on the rise worldwide ${ }^{21,22}$.

In developing countries, guidelines for acute diarrhea suggest that the presence of blood in the stools should always be checked. Non-bloody diarrhea should be managed with fluids only (unless co-morbidities are present that may require a different treatment), while dysentery (reported history of blood in the stools 
since diarrheal onset) should be managed with antibiotics, as Shigella infection is suspected ${ }^{23}$. This approach is supported by the evidence that most non-bloody diarrheal episodes in children under 5 years of age in low-income settings are self-limiting and are caused by viral pathogens (rotavirus, norovirus, astrovirus, and enteric adenovirus) or pathogens for which antibiotics are likely of limited efficacy or even dangerous (e.g. Salmonellae and Campylobacter) ${ }^{24}$. In contrast, a significant proportion of episodes of bloody diarrhea caused by Shigella is associated with considerable mortality and should be treated with antibiotic therapy ${ }^{25}$. However, inappropriate antibiotic use remains common. In a study in 447 Indian children aged between 6 months and 5 years, deviations from WHO protocol for AGE treatment were found in $78 \%$ of $\operatorname{cases}^{26,27}$. Although in all cases oral rehydration solution and zinc were prescribed, unnecessary antibiotic use was reported in $12 \%$ of cases, with cefixime, ofloxacin, and ceftriaxone being the most frequently prescribed antibiotics. Hospitalization, longer duration of symptoms prior to presentation, and fever were associated with prescription of antibiotics $^{27}$. In other studies, the type of physician was related to antibiotic prescription. Pediatricians working in the government sector prescribed antibiotics to only $23 \%$ of children, while private practitioners prescribed antibiotics to $51 \%$ of children with diarrhea ${ }^{28}$.

Also, in developed countries, over-prescription of antibiotics for AGE was reported, and physician responses to patients' treatment expectations was an important cause of inappropriate antibiotic use ${ }^{29}$. However, in as many as $10 \%$ of children admitted to hospital, unnecessary antimicrobial therapy is prescribed because of a "probable bacterial cause" ${ }^{30}$.

\section{Indications for antimicrobial treatment of acute gastroenteritis}

In adults, single cases of acute febrile bloody diarrhea are more likely to be caused by bacterial pathogens such as Campylobacter or Shigella species, depending on the epidemiological setting. These patients are likely to benefit from empirical antimicrobial therapy ${ }^{31}$.
In children, there are no clear or validated criteria for antibiotic therapy. However, the criteria for considering antibiotic treatment include clinical features, host-related and setting-related conditions, and, of course, etiology.

Because the etiology of diarrhea is not generally looked for, the decision to treat children with AGE with antibiotics should be based on the presence of factors that "may require" antibiotic treatment (see Table 1 and Table 2). Generally, antibiotic choice should be initially empiric and subsequently tailored on the results of microbiological investigations. In many conditions, waiting for microbiological results to confirm the decision to treat and select the specific drug may be appropriate.

\section{Clinical indications}

The guidelines for the treatment of acute diarrhea in children state that the use of antibiotics is not needed routinely but only for specific pathogens or in defined clinical settings ${ }^{1}$. Clinical indications for antibiotic therapy include toxic state or signs of invasive infection (Table 1). These should be considered as strong indications to parenteral antibiotic treatment. Fever per se does not require antimicrobial therapy but needs to be considered in a more global clinical evaluation. It may indicate dehydration but also spreading of intestinal infection. This could be confirmed by an increase of inflammatory markers such as C-reactive protein. Dysentery presentation with abdominal pain and mucoid or bloody stools (often in multiple outputs of low volume) has been associated with a bacterial etiology (Campylobacter, Salmonella, Shigella, Yersinia). In those circumstances, antibiotic therapy should be provided at least in countries where the mortality rate is consistent or with limited healthcare facilities, according to the WHO. Alternatively, it could be considered but not necessarily given. Microbiological investigation should always be obtained in dysenteric diarrhea, but, in severe cases, empiric therapy should be started while awaiting the results. Finally, a prolonged course of diarrhea in a child who is losing weight also requires microbiological investigation and occasionally empirical antibiotic treatment ${ }^{32}$. Prolonged diarrhea may be caused by a proliferation of intestinal bacteria in the proximal intestine,

Table 1. Clinical conditions and circumstances that may indicate antibiotic therapy.

\begin{tabular}{|c|c|c|}
\hline Condition & Putative bacterial agent & Suggested antibiotic \\
\hline Dysenteric diarrhea & Shigella, Yersinia, Campylobacter & Azithromycin, ciprofloxacin \\
\hline $\begin{array}{l}\text { Fever, increased } \\
\text { inflammation markers }\end{array}$ & Shigella & Azithromycin, ceftriaxone \\
\hline Prolonged diarrhea & $\begin{array}{l}\text { Gram-negative enterobacteria, } \\
\text { Clostridium difficile }\end{array}$ & Metronidazole, co-trimoxazole \\
\hline SIBO & Gram-negative enterobacteria & Metronidazole, rifaximin, co-trimoxazole \\
\hline $\begin{array}{l}\text { Antibiotic-associated } \\
\text { diarrhea }\end{array}$ & Clostridium difficile, others & $\begin{array}{l}\text { Metronidazole, vancomycin } \\
\text { (only if Clostridium difficile is detected) }\end{array}$ \\
\hline Traveler's diarrhea & ETEC, EPEC & Azithromycin, ciprofloxacin \\
\hline Toxic state & $\begin{array}{l}\text { Gram-negative enterobacteria, } \\
\text { Clostridium difficile }\end{array}$ & Ceftriaxone \\
\hline
\end{tabular}

EPEC, enteropathogenic Escherichia coli; ETEC, enterotoxigenic Escherichia coli; SIBO, small intestinal bacterial overgrowth. 
so-called small intestinal bacterial overgrowth (SIBO). A recent paper proposes an interesting explanation of the link among SIBO, infectious irritable bowel syndrome, and tropical sprue, all conditions that are successfully treated with antibiotics ${ }^{33}$. Microbiological results may support the decision to treat with antibiotics. Figure 1 shows the criteria for consideration when deciding on antibiotic treatment for children with infectious diarrhea.
Antibiotic therapy is always recommended for culture-proven (or even suspected) Shigella gastroenteritis. Antibiotic therapy of shigellosis has two purposes: reducing symptoms and sterilizing the source of spreading, since humans are the only host of Shigella. However, effective treatment of shigellosis is complicated by the emergence of strains resistant to ampicillin, trimethoprim-sulfamethoxazole, and tetracycline ${ }^{34}$. Children with non-typhoidal Salmonella gastroenteritis should not be treated

Table 2. Risk factors indicating antibiotic therapy in children with acute diarrhea.

\begin{tabular}{|c|c|}
\hline Risk factors & Evidence \\
\hline \multicolumn{2}{|l|}{ Host-related risk factors } \\
\hline Age $<3$ (or 6 ) months & Poor evidence but strong indication in neonates \\
\hline Severity of clinical presentation & Poor evidence but strong indications \\
\hline Malnutrition & Strong evidence \\
\hline $\begin{array}{l}\text { Chronic underlying disease } \\
\text { Immune deficiency }\end{array}$ & $\begin{array}{l}\text { Strong evidence for children with IBD or HIV } \\
\text { Oncologic patients in immunosuppression } \\
\text { therapy }\end{array}$ \\
\hline \multicolumn{2}{|l|}{ Setting-related risk factors } \\
\hline $\begin{array}{l}\text { Day-care centers, hospitals, } \\
\text { and close institutions }\end{array}$ & $\begin{array}{l}\text { Strong evidence, if spreading of bacterial } \\
\text { infection is an issue }\end{array}$ \\
\hline Traveler's diarrhea & $\begin{array}{l}\text { Strong evidence in adults, poor evidence in } \\
\text { children }\end{array}$ \\
\hline
\end{tabular}

HIV, human immunodeficiency virus; IBD, inflammatory bowel disease.

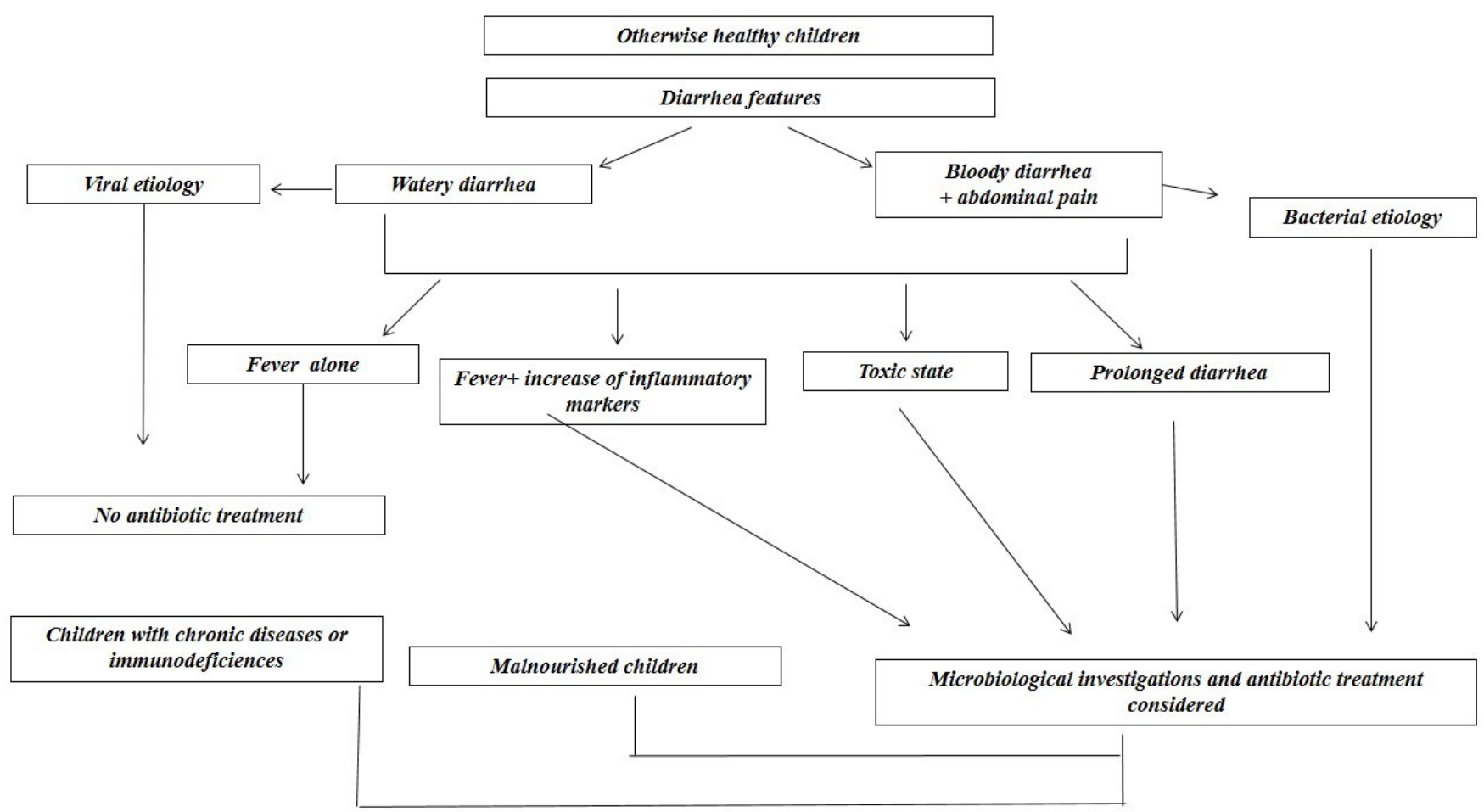

Figure 1. Criteria to decide antibiotic treatment in children with infectious diarrhea. 
routinely with antibiotics because treatment is not effective on symptoms and does not prevent complications; in addition, the use of antibiotics may be associated with a prolonged fecal excretion of Salmonella ${ }^{1}$. Antibiotic therapy for Campylobacter gastroenteritis is recommended mainly for the dysenteric form and to reduce transmission in day-care centers and institutions. However, antibiotics are effective in reducing symptoms only if started in the early stage of the disease (within 3 days of onset).

\section{Host-related indications}

Host-related indications include age, the finding of specific pathogens, the presence of chronic underlying diseases, immune suppression, and malnutrition (see Table 2).

Age. AGE in neonates should be treated with antibiotics. Also, young infants (under 3 to 6 months of age) are candidates for antimicrobial therapy according to expert opinion, although there is no supporting evidence ${ }^{1}$. In infants under 3 months of age, microbiology should always be obtained and antimicrobial treatment should be considered. If diarrhea is severe or if there are signs or clinical symptoms of general infection, or also if symptoms are worsening after 3 or more days from their onset, antibiotic therapy should be started.

Chronic conditions. International guidelines state that children with underlying immune deficiency, anatomical or functional asplenia, corticosteroid or immunosuppressive therapy, cancer, inflammatory bowel disease (IBD), or achlorhydria should receive antibiotics when bacterial gastroenteritis is suspected. Although this approach appears logical, data on efficacy are lacking, the grade of evidence is weak, and there is no list of specific chronic conditions that require antibiotic therapy for diarrhea.

Selected agents are associated with immunodeficiency or other specific diseases, and the major bacterial opportunistic agent is Cd.

Cd has reached epidemic proportions, particularly in industrialized nations. $\mathrm{Cd}$ is a major agent of antibiotic-induced diarrhea and of severe diarrhea in children with underlying chronic conditions such as IBDs as well as oncologic diseases. Cd is also responsible for self-limiting, sporadic cases of AGE in children, although its pathogenic role is limited or questionable in children under 36 months of age because of the high frequency of carriers $^{35}$. Cd-induced antibiotic diarrhea often resolves by discontinuation of the antibiotic. However, hypervirulent strains may induce severe symptoms and should be treated with oral metronidazole or vancomycin ${ }^{36}$. For moderate or severe disease particularly in oncologic patients, the first-line treatment is oral metronidazole $(30 \mathrm{mg} / \mathrm{kg} /$ day); oral vancomycin is reserved for resistant strains ${ }^{37,38}$. If antibiotic therapy fails, fecal transplantation remains a feasible and effective option ${ }^{37}$.

Patients with IBD are at increased risk of Cd infection. An increased incidence of $\mathrm{Cd}$ infections in this population has been reported also in pediatric patients ${ }^{37,39}$. Nevertheless, there are substantial problems in defining the role of $\mathrm{Cd}$ owing to the frequent asymptomatic status. IBD patients have a higher asymptomatic Cd carriage status: as high as $8 \%$ compared to a rate of $1 \%$ in healthy subjects ${ }^{40}$. Antibiotic exposure seems to be a less important factor for clinically significant $\mathrm{Cd}$ infections in IBD patients. The proposed mechanism of $\mathrm{Cd}$ infections involves an alteration of the intestinal flora ${ }^{8}$. In addition, clinically, IBD exacerbations and $\mathrm{Cd}$ infections are similar in the IBD population, with bloody diarrhea and systemic symptoms, such as fever, malaise, anorexia, leukocytosis, hypoalbuminemia, and stool leukocytes in both conditions. Antibiotics may be useful, although in both IBD patients and oncologic patients there is a paucity of evidence to guide antibiotic choice. Metronidazole has been associated with a high rate of failure, and it may be reasonable to consider vancomycin as first-line treatment of severe cases $^{41}$.

However, all the international guidelines recommend microbiological examination and to start metronidazole or ciprofloxacin in IBD children with diarrhea recurrence. Again, there are no controlled studies to support this albeit reasonable strategy. Also, in children with cancer, intestinal infections are a major threat and require a comprehensive diagnostic approach ${ }^{38}$.

Immunocompromised patients. The major source of information on the link between incidence and severity of gastrointestinal infections and immunodeficiency is derived from children with AIDS. In 2010, a study from Kenya showed that diarrhea was more common among human immunodeficiency virus (HIV)positive children than among HIV-negative children (321 versus 183 episodes respectively, $p<0.01$ ) and that diarrhea was associated with a $40 \%$ fatality rate. In addition, HIV-positive infants were significantly more likely to experience persistent diarrhea than HIV-negative infants $(p<0.01)$. Although diarrhea was more common among HIV-infected children, bacterial pathogens such as Campylobacter and Shigella were not frequent, suggesting that other pathogens (e.g. viruses, parasites, diarrheagenic E. coli) or other causes (e.g. malabsorption, metabolic enteritis) may be important in this population ${ }^{42}$. However, Cryptosporidium parvum is the classical agent of diarrhea in severely immunodeficient children, and its detection is considered a hallmark of severe disease. HIV itself can act as an enteric pathogen through the production of an enterotoxic effect ${ }^{43}$.

Malnutrition. Children with severe acute malnutrition (SAM) who present with AGE are generally treated with broad-spectrum antibiotics, even in the absence of overt infection. The rationale is that (a) malnourished children frequently have bacterial infections (including bacteremia), (b) the diagnosis of infection in malnourished children is difficult because clinical manifestations (e.g. fever) may not be apparent, and (c) malnourished children have an increased risk of small intestinal overgrowth. However, while this approach has a rational basis, there is very little evidence of its efficacy. A study from Malawi clearly demonstrated the importance of antibiotic administration to children with SAM even without evident clinical features of infection: 2,767 children with SAM eligible for outpatient care and aged 6-59 months were randomized to 7 days of treatment with oral amoxicillin, cefdinir, or placebo. The 12-week mortality rates were $4.8 \%$ (amoxicillin), $4.1 \%$ (cefdinir), and $7.4 \%$ (placebo), with a relative mortality risk for placebo compared with amoxicillin of 1.55 (95\% CI 1.07-2.24) and for placebo compared with cefdinir of $1.80(95 \% \text { CI } 1.22-2.64)^{44}$. SAM is associated with 
an increased mortality from infectious diseases, suggesting that children with SAM are severely immunologically impaired. However, the precise mechanisms underlying this relationship are unclear. Diarrhea and malnutrition are common in young children in developing countries, and malnutrition is associated with increased severity of common infections. Death of severely malnourished children is often the result of an infection. Children with AGE were significantly more likely to have malnutrition $(\mathrm{OR}=8.57 ; p<0.001)$, and malnutrition status was the only independent factor associated with infection $(\mathrm{OR}=8.37 ; p<0.001)^{45}$. Environmental enteropathy, recently redefined as environmental enteric dysfunction, is the combined result of undernutrition, repeated infections, and environment-related toxic damages occurring in early life, requiring a comprehensive approach with antiinfective drugs, hygiene measures, and nutritional rehabilitation to prevent subsequent severe disabilities ${ }^{46}$. Therefore, the management of infection should be different in malnourished versus wellnourished children, and a more aggressive antimicrobial strategy is indicated in the former.

\section{Choice of antimicrobial agent}

In the past 10 years, new molecular diagnostic tests with a multiplex polymerase chain reaction (PCR) panel have been developed. They are faster than traditional tests, have a higher sensitivity, and have the possibility to simultaneously test a wide range of agents ${ }^{47}$. Molecular diagnostics would enable the physician to initiate timely and targeted antibiotic therapy. Early empiric antibiotic therapy will remain the therapy of choice for severely affected patients.

The decision to treat a child with AGE and the choice of antimicrobial drug is challenging. There is a relatively broad pattern of pathogens according to age, location, season, vaccine policy (against rotavirus and others), and symptoms ${ }^{48,49}$. Furthermore, infections with multiple pathogens, which are common among children with diarrhea, complicate treatment. Antimicrobial resistance should also be considered in the antibiotic choice. Knowledge of the local pattern of resistance is crucial to reduce the number of failures. Antibiotic selection is based on two major considerations: the chance of obtaining microbiological results, including resistance pattern, and the severity of clinical conditions.

The WHO recommends treating all episodes of blood in the stools with antibiotics and to use ciprofloxacin as the first-line drug. Alternatives are pivmecillinam, azithromycin, and ceftriaxone $^{50}$. This recommendation has been confirmed, although in recent years the rates of resistance are increasing ${ }^{25}$. Fluoroquinolones are often empirically used in adults, and cephalosporins are used to treat children with suspected bacterial AGE. Fluoroquinolones are effective against a wide variety of enteric infections in adults, including shigellosis, salmonellosis, typhoid fever, cholera, and Campylobacter infections. Like all quinolones, ciprofloxacin causes arthropathic effects in immature animals and their use has been limited in children. However, several studies have confirmed the safety of ciprofloxacin use in the pediatric age group. Because of low cost and the availability of an oral formulation, ciprofloxacin plays an important role in the treatment of childhood acute invasive diarrhea, especially in poor countries.

Often, in severe conditions, early empiric therapy is needed while awaiting the results of investigations. If clinical conditions are severe, parenteral therapy should be started soon. For parenteral therapy of diarrhea, ceftriaxone or ciprofloxacin may be considered, as both are effective against Gram-negative bacteria. In children with chronic conditions, metronidazole provides an alternative option, as it is also effective against $\mathrm{Cd}$. Oral metronidazole can be considered for sequential therapy after parenteral administration. Oral metronidazole is used for prolonged diarrhea, although there is little evidence of efficacy of antibiotics $^{32}$.

SIBO is another indication for antibiotics. It may be difficult to diagnose, as quantitative cultures of duodenal aspirate as well as the breath hydrogen test are neither standardized nor reliable ${ }^{51}$. Co-trimoxazole and metronidazole are first-line drugs ${ }^{52}$. The latter is effective for bacterial agents, including $\mathrm{Cd}$, as well as against Giardia lamblia-all agents implicated in prolonged diarrhea. Recently, rifaximin has been used in clinical (uncontrolled) trials with good results ${ }^{53}$.

Co-trimoxazole is still largely used in the antimicrobial therapy of diarrhea. It has been effective in malnutrition and HIV-related enteropathy and is a major drug with multiple indications in developing countries ${ }^{54}$.

In high-income countries, untargeted antibiotic therapy should be avoided. However, azithromycin is the drug of choice for treating campylobacteriosis and is also appropriate for treating shigellosis ${ }^{1}$. The duration of treatment is $3-5$ days.

Non-typhoidal Salmonella infections are common in many settings and endemic in European children. Usually, they cause mild, self-limiting gastroenteritis. However, bacteremia may be a complication-particularly in immunocompromised children, in those with sickle cell disease, and in young infants-and in those children antibiotic therapy should be considered ${ }^{55}$. Recommended empiric oral treatment of non-typhoidal salmonellae includes amoxicillin, azithromycin, or co-trimoxazole and should be considered for at-risk children in relatively good clinical conditions. Parenteral therapy should be started in children with bacteremia or in those with complicated infections (focal or invasive) and includes cefotaxime or ceftriaxone at high dose (ceftriaxone $100 \mathrm{mg} / \mathrm{kg} /$ day $)^{56}$.

In the case of traveler's diarrhea, antibiotic treatment is effective in reducing the duration and severity of diarrhea. Because of the high rates of resistance to ampicillin and trimethoprimsulfamethoxazole, currently the drugs recommended include azithromycin, ciprofloxacin, and rifaximin ${ }^{57}$. Rifaximin may be considered as a first-line treatment option in adults with uncomplicated traveler's diarrhea because of its favorable efficacy, tolerability, and safety profiles ${ }^{57}$.

The choice of antibiotic therapy based on etiology is summarized in Table 3. 
Table 3. Antibiotic choice based on etiology.

\begin{tabular}{|c|c|c|c|}
\hline Organism & Preferred therapy & Alternative agents & Efficacy \\
\hline Campylobacter jejuni & Azithromycin & $\begin{array}{l}\text { Ciprofloxacin, } \\
\text { vancomycin }\end{array}$ & $\begin{array}{l}\text { Proven if started within } 3 \text { days of } \\
\text { symptom onset }\end{array}$ \\
\hline Clostridium difficile & Metronidazole & Vancomycin & Proven in severe cases \\
\hline $\begin{array}{l}\text { Non-typhoidal } \\
\text { Salmonella }\end{array}$ & Amoxicillin or ceftriaxone & $\begin{array}{l}\text { Trimethoprim- } \\
\text { sulfamethoxazole }\end{array}$ & $\begin{array}{l}\text { Proven in children with toxic status, } \\
\text { in children under } 3 \text { months of age, } \\
\text { in at-risk children, and if systemic } \\
\text { or focal infections }\end{array}$ \\
\hline Salmonella typhi & $\begin{array}{l}\text { Third-generation } \\
\text { cephalosporins }\end{array}$ & Chloramphenicol & Proven \\
\hline Shigella & Azithromycin, ceftriaxone & Cefixime, ciprofloxacin & Proven \\
\hline Yersinia & $\begin{array}{l}\text { Trimethoprim- } \\
\text { sulfamethoxazole }\end{array}$ & Ceftriaxone & $\begin{array}{l}\text { Proven in severe disease or } \\
\text { bacteremia }\end{array}$ \\
\hline Vibrio cholerae & Azithromycin & $\begin{array}{l}\text { Doxycycline } \\
\text { ( }>8 \text { years), ciprofloxacin }\end{array}$ & $\begin{array}{l}\text { Reduces duration by } 50 \% \text { and } \\
\text { shedding }\end{array}$ \\
\hline ETEC & $\begin{array}{l}\text { Azithromycin (only for } \\
\text { traveler's diarrhea) }\end{array}$ & $\begin{array}{l}\text { Trimethoprim- } \\
\text { sulfamethoxazole }\end{array}$ & To be considered in selected cases \\
\hline
\end{tabular}

ETEC, enterotoxigenic Escherichia coli.

\section{Conclusions}

Rehydration is the key treatment for AGE, and active treatment of diarrhea with probiotics or diosmectite should always be considered, independent of etiology. Antibiotics are generally not necessary and can even be harmful in children, but they should be given in selected circumstances. There are three distinct sets of criteria that should be carefully considered: clinical conditions, host-related factors, and setting. When there is a potential indication for antibiotics, microbiological investigations should always be obtained prior to the start of therapy. Empiric antibiotic therapy should be started soon after specimen collection in infants and children in severe conditions. Cotrimoxazole and metronidazole are to be considered for oral administration. Azithromycin and rifaximin may also be used, based on local consideration or if signs of colitis are observed. Ceftriaxone, metronidazole, and ciprofloxacin may be considered in children with systemic and invasive diseases. Young infants, children with chronic conditions, and those in a toxic state or with signs of systemic infection should be considered at risk of systemic infections, and oral or parenteral antibiotic therapy may be indicated. If mild symptoms are present and close observation is feasible, it may be better to wait for microbiological results. Antibiotic therapy in specific settings is also indicated if spreading is an issue. Traveler's diarrhea may require antibiotic therapy. The choice of specific antibiotic should be based on etiology and local resistance pattern.

In conclusion, while it is important to reduce the use of unnecessary antibiotics, there are circumstances in which these drugs are needed and are potentially life-saving. However, their use is far from being supported by evidence and requires careful consideration of clinical and epidemiological issues.

\section{Abbreviations}

AGE, acute gastroenteritis; EAEC, enteroaggregative Escherichia coli; EPEC, enteropathogenic Escherichia coli; ETEC, enterotoxigenic Esherichia coli; Cd, Clostridium difficile; HIV, human immunodeficiency virus; IBD, inflammatory bowel disease; SAM, severe acute malnutrition; SIBO, small intestinal bacterial overgrowth; WHO, World Health Organization.

\section{Competing interests}

The authors declare that they have no competing interests.

\section{Grant information}

The author(s) declared that no grants were involved in supporting this work.

\section{Acknowledgements}

AG conceived the study. AGi and EB carried out the systematic literature research. AGi and EB prepared the first draft. AG provided substantial contribution to the preparation of the manuscript. EB and AGi prepared figures and tables. All authors were involved in the revision of the draft manuscript and have agreed to the final content. 
1. Guarino A, Ashkenazi S, Gendrel D, et al: European Society for Pediatric Gastroenterology, Hepatology, and Nutrition/European Society for Pediatric Infectious Diseases evidence-based guidelines for the management of acute gastroenteritis in children in Europe: update 2014. J Pediatr Gastroenterol Nutr. 2014; 59(1): 132-52.

PubMed Abstract | Publisher Full Text

2. F Lübbert C: Antimicrobial therapy of acute diarrhoea: a clinical review. Expert Rev Anti Infect Ther. 2016; 14(2): 193-206. PubMed Abstract | Publisher Full Text | F1000 Recommendation

3. F Liu J, Platts-Mills JA, Juma J, et al: Use of quantitative molecular diagnostic methods to identify causes of diarrhoea in children: a reanalysis of the GEMS case-control study. Lancet. 2016; 388(10051): 1291-301.

PubMed Abstract | Publisher Full Text | Free Full Text | F1000 Recommendation

4. $\quad \mathrm{F}$ Kotloff KL: The Burden and Etiology of Diarrheal Illness in Developing Countries. Pediatr Clin North Am. 2017; 64(4): 799-814.

PubMed Abstract | Publisher Full Text | F1000 Recommendation

5. Bartels C, Beaute J, Fraser G, et al:: Annual epidemiological report 2014: foodand waterborne diseases and zoonoses. Stockholm: ECDC; 2014 Reference Source

6. F Spina A, Kerr KG, Cormican M, et al:: Spectrum of enteropathogens detected by the FilmArray GI Panel in a multicentre study of communityacquired gastroenteritis. Clin Microbiol Infect. 2015; 21(8): 719-28. PubMed Abstract | Publisher Full Text | F1000 Recommendation

7. Huhulescu S, Kiss R, Brettlecker M, et al.: Etiology of acute gastroenteritis in three sentinel general practices, Austria 2007. Infection. 2009; 37(2): 103-8. PubMed Abstract | Publisher Full Text

8. $\quad \mathrm{F}$ Tang $\mathrm{YM}$, Stone $\mathrm{CD}$ : Clostridium difficile infection in inflammatory bowe disease: challenges in diagnosis and treatment. Clin J Gastroenterol. 2017; 10(2): 112-23.

PubMed Abstract | Publisher Full Text | F1000 Recommendation

9. Lo Vecchio A, Lancella L, Tagliabue $\mathrm{C}$, et al:: Clostridium difficile infection in children: epidemiology and risk of recurrence in a low-prevalence country. Eur J Clin Microbiol Infect Dis. 2017; 36(1): 177-85.

PubMed Abstract | Publisher Full Text

10. Vasco G, Trueba G, Atherton R, et al:: Identifying etiological agents causing diarrhea in low income Ecuadorian communities. Am J Trop Med Hyg. 2014; 91(3): 563-9.

PubMed Abstract | Publisher Full Text | Free Full Text

11. F Tian L, Zhu X, Chen Z, et al.: Characteristics of bacterial pathogens associated with acute diarrhea in children under 5 years of age: a hospitalbased cross-sectional study. BMC Infect Dis. 2016; 16: 253. PubMed Abstract | Publisher Full Text | Free Full Text | F1000 Recommendation

12. $\mathrm{F}$ Wang $\mathrm{X}$, Wang J, Sun $\mathrm{H}$, et al: Etiology of Childhood Infectious Diarrhea in a Developed Region of China: Compared to Childhood Diarrhea in a Developing Region and Adult Diarrhea in a Developed Region. PLoS One. 2015; 10(11): e0142136.

PubMed Abstract | Publisher Full Text | Free Full Text | F1000 Recommendation

13. F Shrivastava AK, Kumar S, Mohakud NK, et al.: Multiple etiologies of infectious diarrhea and concurrent infections in a pediatric outpatient-based screening study in Odisha, India. Gut Pathog. 2017; 9: 16. PubMed Abstract | Publisher Full Text | Free Full Text | F1000 Recommendation

14. Giddings SL, Stevens AM, Leung DT: Traveler's Diarrhea. Med Clin North Am. 2016; 100(2): 317-30.

PubMed Abstract | Publisher Full Text | Free Full Text

15. Cameron D, Hock QS, Kadim M, et al.: Probiotics for gastrointestinal disorders: Proposed recommendations for children of the Asia-Pacific region. World $J$ Gastroenterol. 2017; 23(45): 7952-64.

PubMed Abstract | Publisher Full Text | Free Full Text

16. World Health Organization: Acute Diarrhea in Adults and Children: A Global Perspective. 2012

Reference Source

17. Academy of Medicine of Malaysia: Guidelines on the management of Acute Diarrhoea in children. 2011. Reference Source

18. Wittenberg DF: Management guidelines for acute infective diarrhoea / gastroenteritis in infants. S Afr Med J. 2012; 102(2): 104-7. PubMed Abstract

19. Adachi JA, Ostrosky-Zeichner L, DuPont HL, et al:: Empirical antimicrobia therapy for traveler's diarrhea. Clin Infect Dis. 2000; 31(4): 1079-83. PubMed Abstract | Publisher Full Tex

20. Zollner-Schwetz I, Krause R: Therapy of acute gastroenteritis: role of antibiotics. Clin Microbiol Infect. 2015; 21(8): 744-9. PubMed Abstract | Publisher Full Tex

21. F Humphries RM, Schuetz AN: Antimicrobial susceptibility testing of bacteria that cause gastroenteritis. Clin Lab Med. 2015; 35(2): 313-31. PubMed Abstract | Publisher Full Text | F1000 Recommendation
22. Okeke IN, Aboderin OA, Byarugaba DK, et al:: Growing problem of multidrugresistant enteric pathogens in Africa. Emerging Infect Dis. 2007; 13(11): 1640-6. PubMed Abstract | Publisher Full Text | Free Full Text

23. World Health Organization: Chart Booklet: Integrated Management of Childhood IIIness. Geneva: World Health Organization; 2014.

Reference Source

24. O'Ryan M, Prado V, Pickering LK: A millennium update on pediatric diarrheal illness in the developing world. Semin Pediatr Infect Dis. 2005; 16(2): 125-36. PubMed Abstract | Publisher Full Text

25. Traa BS, Walker CL, Munos M, et al:: Antibiotics for the treatment of dysentery in children. Int J Epidemiol. 2010; 39(Suppl 1): i70-4. PubMed Abstract | Publisher Full Text | Free Full Text

26. World Health Organization: The treatment of diarrhea: A manual for physicians and other senior health workers. 4th rev. Department of Child and Adolescent Health and Development, Geneva: World Health Organization; 2005. Reference Source

27. F De T, Kondekar S, Rathi S: Hospital Based Prospective Observational Study to Audit the Prescription Practices and Outcomes of Paediatric Patients (6 months to 5 years age group) Presenting with Acute Diarrhea. J Clin Diagn Res. 2016; 10(5): SC01-5.

PubMed Abstract | Publisher Full Text | Free Full Text | F1000 Recommendation

28. Kotwani A, Chaudhury RR, Holloway K: Antibiotic-prescribing practices of primary care prescribers for acute diarrhea in New Delhi, India. Value Health. 2012; 15(1 Suppl): S116-9.

PubMed Abstract | Publisher Full Tex

29. Fleming-Dutra KE, Mangione-Smith R, Hicks LA: How to Prescribe Fewer Unnecessary Antibiotics: Talking Points That Work with Patients and Their Families. Am Fam Physician. 2016; 94(3): 200-2. PubMed Abstract

30. Lo Vecchio A, Liguoro I, Bruzzese D, et al.: Adherence to guidelines for management of children hospitalized for acute diarrhea. Pediatr Infect Dis $\mathrm{J}$. 2014: 33(11): 1103-8.

PubMed Abstract | Publisher Full Tex

31. $\mathrm{F}$ DuPont $\mathrm{HL}$ : Acute infectious diarrhea in immunocompetent adults. $N$ Engl $\mathrm{J}$ Med. 2014; 370(16): 1532-40.

PubMed Abstract | Publisher Full Text | F1000 Recommendation

32. Giannattasio A, Guarino A, Lo Vecchio A: Management of children with prolonged diarrhea [version 1; referees: 3 approved]. F1000Res. 2016; 5 pii: F1000 Faculty Rev-206. PubMed Abstract | Publisher Full Text | Free Full Tex

33. F Ghoshal UC, Gwee KA: Post-infectious IBS, tropical sprue and small intestinal bacterial overgrowth: the missing link. Nat Rev Gastroenterol Hepatol. 2017; 14(7): 435-41.

PubMed Abstract | Publisher Full Text | F1000 Recommendation

34. F Abd-Elmeged GM, Khairy RM, Abo-Eloyoon SM, et al.: Changing patterns of drug-resistant Shigella isolates in egypt. Microb Drug Resist. 2015; 21(3): 286-91.

PubMed Abstract | Publisher Full Text | F1000 Recommendation

35. F Lessa FC, Mu Y, Bamberg WM, et al:: Burden of Clostridium difficile infection in the United States. N Engl J Med. 2015; 372(9): 825-34. PubMed Abstract | Publisher Full Text | F1000 Recommendation

36. Schutze GE, Willoughby RE: Clostridium difficile infection in infants and children. Pediatrics. 2013; 131(1): 196-200. PubMed Abstract | Publisher Full Text

37. Lo Vecchio A, Zacur GM: Clostridium difficile infection: an update on epidemiology, risk factors, and therapeutic options. Curr Opin Gastroenterol. 2012; 28(1): 1-9. PubMed Abstract | Publisher Full Text

38. Castagnola E, Ruberto E, Guarino A: Gastrointestinal and liver infections in children undergoing antineoplastic chemotherapy in the years 2000. World $J$ Gastroenterol. 2016; 22(25): 5853-66. PubMed Abstract | Publisher Full Text | Free Full Text

39. Martinelli M, Strisciuglio C, Veres G, et al:: Clostridium difficile and pediatric inflammatory bowel disease: a prospective, comparative, multicenter, ESPGHAN study. Inflamm Bowel Dis. 2014; 20(12): 2219-25. PubMed Abstract | Publisher Full Text

40. Clayton EM, Rea MC, Shanahan F, et al:: The vexed relationship between Clostridium difficile and inflammatory bowel disease: an assessment of carriage in an outpatient setting among patients in remission. $A m$ Gastroenterol. 2009; 104(5): 1162-9. PubMed Abstract | Publisher Full Text

41. Nitzan O, Elias M, Chazan B, et al.: Clostridium difficile and inflammatory bowel disease: role in pathogenesis and implications in treatment. World $J$ Gastroenterol. 2013; 19(43): 7577-85. PubMed Abstract | Publisher Full Text | Free Full Text

42. van Eijk AM, Brooks JT, Adcock PM, et al:: Diarrhea in children less than two years of age with known HIV status in Kisumu, Kenya. Int J Infect Dis. 2010; 
14(3): e220-5.

PubMed Abstract | Publisher Full Text

43. Buccigrossi V, Laudiero G, Nicastro E, et al:: The HIV-1 transactivator factor (Tat) induces enterocyte apoptosis through a redox-mediated mechanism. PLOS One. 2011; 6(12): e29436.

PubMed Abstract | Publisher Full Text | Free Full Text

44. F Trehan I, Goldbach HS, LaGrone LN, et al:: Antibiotics as part of the management of severe acute malnutrition. N Engl J Med. 2013; 368(5): 425-35. PubMed Abstract | Publisher Full Text | Free Full Text | F1000 Recommendation

45. Al Jarousha AM, El Jarou MA, El Qouqa IA: Bacterial enteropathogens and risk factors associated with childhood diarrhea. Indian J Pediatr. 2011; 78(2): 165-70.

PubMed Abstract | Publisher Full Text

46. Trehan I, Kelly $\mathrm{P}$, Shaikh $\mathrm{N}$, et al:: New insights into environmental enteric dysfunction. Arch Dis Child. 2016; 101(8): 741-4.

PubMed Abstract | Publisher Full Text

47. Guarino A, Giannattasio A: New molecular approaches in the diagnosis of acut diarrhea: advantages for clinicians and researchers. Curr Opin Gastroenterol. 2011; 27(1): 24-9.

PubMed Abstract | Publisher Full Text

48. F GBD Diarrhoeal Diseases Collaborators: Estimates of global, regional, and national morbidity, mortality, and aetiologies of diarrhoeal diseases: a systematic analysis for the Global Burden of Disease Study 2015. Lancet Infect Dis. 2017; 17(9): 909-48.

PubMed Abstract | Publisher Full Text | Free Full Text | F1000 Recommendation

49. Lo Vecchio A, Liguoro I, Dias JA, et al.: Rotavirus immunization: Global coverage and local barriers for implementation. Vaccine. 2017; 35(12): 1637-44. PubMed Abstract | Publisher Full Text

50. World Health Organization, Department of Child and Adolescent Health and
Development: Guidelines for the control of shigellosis, including epidemics due to Shigella dysenteriae Type 1. Geneva, 2005.

Reference Source

51. F Sieczkowska A, Landowski P, Kaminska B, et al.: Small Bowel Bacteria Overgrowth in Children. J Pediatr Gastroenterol Nutr. 2016; 62(2): 196-207. PubMed Abstract | Publisher Full Text | F1000 Recommendation

52. Tahan S, Melli LC, Mello CS, et al:: Effectiveness of trimethoprimsulfamethoxazole and metronidazole in the treatment of small intestinal bacterial overgrowth in children living in a slum. $J$ Pediatr Gastroenterol Nutr. 2013; 57(3): 316-8. PubMed Abstract | Publisher Full Text

53. Scarpellini E, Giorgio V, Gabrielli M, et al.: Rifaximin treatment for small intestinal bacterial overgrowth in children with irritable bowel syndrome. Eur Rev Med Pharmacol Sci. 2013; 17(10): 1314-20. PubMed Abstract

54. F Church JA, Fitzgerald F, Walker AS, et al:: The expanding role of cotrimoxazole in developing countries. Lancet Infect Dis. 2015; 15(3): 327-39. PubMed Abstract | Publisher Full Text | F1000 Recommendation

55. Bula-Rudas FJ, Rathore MH, Maraqa NF: Salmonella Infections in Childhood. Adv Pediatr. 2015; 62(1): 29-58. PubMed Abstract | Publisher Full Text

56. F Wen SC, Best E, Nourse C: Non-typhoidal Salmonella infections in children Review of literature and recommendations for management. J Paediatr Child Health. 2017; 53(10): 936-41.

PubMed Abstract | Publisher Full Text | F1000 Recommendation

57. de la Cabada Bauche J, DuPont HL: New Developments in Traveler's Diarrhea. Gastroenterol Hepatol (N Y). 2011; 7(2): 88-95.

PubMed Abstract | Free Full Text 


\section{Open Peer Review}

\section{Current Peer Review Status:}

\section{Editorial Note on the Review Process}

Faculty Reviews are review articles written by the prestigious Members of Faculty Opinions. The articles are commissioned and peer reviewed before publication to ensure that the final, published version is comprehensive and accessible. The reviewers who approved the final version are listed with their names and affiliations.

\section{The reviewers who approved this article are:}

\section{Version 1}

\section{Zulfiqar Bhutta}

Centre for Global Child Health, The Hospital for Sick Children, Toronto, ON, Canada

Competing Interests: No competing interests were disclosed.

\section{Stephen Baker}

Centre for Tropical Medicine, University of Oxford, Oxford, UK

Competing Interests: No competing interests were disclosed.

The benefits of publishing with F1000Research:

- Your article is published within days, with no editorial bias

- You can publish traditional articles, null/negative results, case reports, data notes and more

- The peer review process is transparent and collaborative

- Your article is indexed in PubMed after passing peer review

- Dedicated customer support at every stage

For pre-submission enquiries, contact research@f1000.com 